\title{
Formation And Development Of Military Architecture In Fergana (Antiquity, Early Middle Ages)
}

\section{Dedakhanov Bakhodir}

Department of technology of production of building materials products and structures, Faculty of construction technology, Namangan engineering construction institute, Namangan, Uzbekistan.

E-mail: dedaxanovbaxodir58@gmail.com

Article History: Received:11 January 2021; Accepted: 27 February 2021; Published online: 5 April 2021

Abstract: The article reveals the problem of the development of military architecture in the territory of ancient Fergana, based on the long-term research of archaeologists of Uzbekistan. It identifies the main factors that have contributed to the improvement of this architecture. In each separately taken historical period, starting from the Bronze Age, the author defines the characteristic features of the fortification architecture of Fergana cities based on specific examples. At the same time, a comparative analysis with neighboring historical and cultural regions (Sogd and Khorezm) is performed, and the issues of the continuity of traditions and evolutionary development in this type of structure are revealed using the examples of military architecture of the early medieval period.

Keywords: Planning, military architecture, fortification, citadel, mud brick, fortress wall, fortification, relief, tower.

\section{Introduction}

The military architecture of Central Asia in the period of antiquity and early Middle Ages, in comparison with other types of structures, remains an issue poorly studied and insufficiently covered. At present, there is substantial data obtained in many years of research by archaeologists on the issues of fortress architecture in ancient cities of historical and cultural regions of Uzbekistan: Khorezm, Sogd, Bactria (Tokharistan), Fergana, etc. This issue was covered in the studies of G.A. Pugachenkova [17], Yu.A. Zadneprovsky [15], E.V. Rtveladze [19], M. Turebekov [21], G.L. Semenov [20], B.M. Abdullaev [4] and others. This article gives an attempt to generalize research on the military architecture of ancient Fergana and to analyze its formation and development.

\section{Material and Methods}

It should be noted that among the factors that contributed to the development and improvement of the military architecture of ancient Fergana, we can name active processes of historical events that stimulated the defense system (for example, the development and strengthening of the Davan state); the development of society and the many-sided strengthening of the state itself; the role of nomads, "militarily more professional, who in a short time subjugated the cities and agricultural oases to their power" [5], and the development of military technology and the tactics of military operations. The military architecture of the Fergana Valley of the ancient period can be periodically considered in the example of the Chust period (late II - early I millennium BC), Eilatan (VII-IV centuries BC), Shurabashat (IV-I centuries BC), and Markhamat periods (I-IV centuries). The earliest examples of settlement protection in the area in question date back to the Bronze Age.

\section{Research Results}

Chust period. The appearance of the walls is explained by the fact that the relations between the agricultural and Andronian cultures were not always peaceful [14, p. 204]. Accordingly, during that period, the need to protect property arose. Initially, ancient structures repeated the relief of the area - they were expediently built on hills, at the confluence of rivers, near the swamps and lakes. In order to ensure stronger military security, along with natural features (a natural obstacle - the sai in Chust), the fortress walls were also erected. This type of structures differed from similar structures in the agricultural south of Central Asia by the complex configuration of walls (by the arched form in the Chust settlement and a length of $64 \mathrm{~m}$ ), the presence of additional platforms outside the walls (Chust, Dalverzin) and higher resistance to precipitation [16, p. 58]. "The walls repeated the contour of the terrain, which violated the clarity of the planning of the Chust settlements" [3, p. 43]. For example, initially Dalverzin - the center of the tribes of the Chust culture - was an open settlement, on the site of the citadel there was a fortified settlement in the form of radially located premises along the periphery; later, it was distinguished by a clear and developed fortification system. Such a defensive system resembles the traditions of the architecture of nomadic tribes. Subsequently, in the process of a sedentary lifestyle and the development of new settlements, there appeared a need for protection, and all three parts of the settlement - the citadel, the residential part and the cattle corral (used as well for the shelter of the population) were simultaneously surrounded by walls of a complex structure made of raw bricks (wall thickness was 4-6 m) [14, p. 101-104]. The military architecture of this settlement, presumably built according to a well-thought-out plan, was distinguished by the use of various techniques (3 techniques) and building materials (compacted soil, mud bricks, pakhsa) [15, p. 151]. Defensive walls were erected only for large and medium-sized fortifications. The main distinguishing feature of the military architecture of that time was the use of strategic capabilities of the relief and its complex configuration (Chust), 
the thickness of the walls (up to $8 \mathrm{~m}$ in Dalverzin and up to $7 \mathrm{~m}$ in Chust), which provided the settlements with high defensive resistance; the presence of additional platforms outside the walls (in Chust an adobe platform was attached to the wall) and the absence of buttress towers.

Eilatan period. The transition to the planned erection of walls in Fergana and the introduction of innovations refer to the Eilatan period, distinguished by a clear and solid system of fortification, however, with some similarities with the previous (Chust) period (in the use of construction techniques - armor lining of walls and materials)и. The clarity in the military architecture can be observed in the example of the Eilatan settlement without the citadel, in which there were double walls (internal and external walls) with shooting chambers and rectangular turrets $(10.5 \times 10 \mathrm{~m})$, located at a distance of 50-60 m from each other, and the near-gate premises flanked by rectangular towers (guardhouses), which made it possible to resist enemies in all directions (walls in Eilatan and Kurgantepa). These walls the thickness of which reached $6 \mathrm{~m}$ and the height of 4.5-5 m, were erected on a platform with external slopes and were built according to a single plan. For example, the construction of the walls of Symtepa (more than $1.5 \mathrm{~m}$ thick) with square towers refers to this period [5, p. 18]. That is, we can say that the fortress walls of that period, characterized by the intensive emergence of urban planning culture, were distinguished by their thoroughness and fundamental nature, and were a kind of achievement in the development of the military architecture of ancient Fergana.

Shurabashat period. The continuation of the military architecture traditions of the Bronze Age (found in the Chust region) can be observed in the example of the Shurabashat settlement: on 3 sides it was surrounded by a river valley and marshy lowlands, and only the fourth side was a defensive wall made of compacted soil. All sections of the city - a citadel on a solid platform, a religious complex, a shelter and a military camp (in the form of a bevel square) - were fortified with independent walls [16, p. 66]. The construction of the walls of the Mingtepa settlement with a fortified citadel $(80 \times 65 \mathrm{~m})$ on a massive stylobate (about $5 \mathrm{~m}$ high) with a vaulted ramp-corridor rise, near-gate structures, two powerful defensive walls $(3.5 \mathrm{~m}$ thick $)$, and numerous rectangular towers $(10.5 \times 5.5$ $\mathrm{m})$ refers to that time. They were 2-tiered and had flat roofing. That period was characterized by a developed fortification with the erection of separated citadels on a solid platform, which were shelters (subrectangular in the plan at the Karadarya settlement), the presence of fortified settlements with fortress walls with a massive base (Sultanabad archaeological complex), with a gallery-corridor (Araltepa fortress in Eastern Fergana) [1, p. 15].

Markhamat period. It should be noted that the military architecture of the capital city and large cities differed from the analogous architecture in agricultural oases, in which more simplified structures were observed. The consistent and dynamic development of military architecture can be observed in the example of Mingtepa (the 2nd century BC - 2nd century AD), which was distinguished by a powerful fortification, in traditions similar to the Parthian system. For this settlement (which served as a capital city of the Davan state), initially (in II-I centuries BC), as noted above, all the basic fortification elements were characteristic. In the Markhamat period, the thickness of the walls gradually increased due to the armor lining - from $4 \mathrm{~m}$ (in the I-II centuries) to $7.3 \mathrm{~m}$ at the base (in the III-IV centuries AD), which made the walls inaccessible for battering rams. Similar elements were observed in Bactria (in Key-Kobad-shah) and Khorezm (Toprakkale). To ensure greater security, the approaches to Mingtepa from the southern side were guarded by fortified settlements (Bilovurtepa) and castles such as Karaulotatepa), which rose $20 \mathrm{~m}$ above the road [2, p. 40]. The capital city of Eski Akhsi also had a powerful fortification, and although no new fortress walls were erected during the Kushan period, and "the nature and basic elements of the fortification did not change" [11, p. 347]; the strengthening of the fortification took place in connection with the invasion of Chinese troops into Fergana (to capture "heavenly horses") [12, p. 58]. While in the II-I centuries BC the width and height of the fortress walls reached $20 \mathrm{~m}$, in the Markhamat period, there appeared the double ditches and rectangular towers, protruding beyond the walls (in the citadel) or rising above the walls; without protruding from the plane (in the second Shakhristan), above which was the battleground [10]. Such a very rare fortification system was a kind of trap and differed from similar walls in the neighboring regions (Sogd and Khorezm), but it had similar features to the fortress architecture in southern Turkmenistan [17, p. 5153]. The walls of the city itself and the citadel of the city-headquarters of Mugtepa (western part of the Kasan settlement) of the Kushan period had a broken pattern, following the natural outlines of the mountain-rocky relief. The fortress architecture of this settlement - a military-political center - was designed for a long-term siege, and characterized by barrage ramparts in front of the gates: "labyrinths", double rows of external walls, a moat with water along the entire perimeter, high towers of various sizes (there are 6 towers in the Shakhristan) with platforms [16, p. 93].

\section{Discussion and Conclusion}

The Kara-Darya settlement had a solid fortification, evidenced by the citadel, towering $10 \mathrm{~m}$ above the settlement (without towers) with defensive walls (up to $3 \mathrm{~m}$ ), by the fortress walls with numerous towers and loopholes, and by labyrinth gates ( in the southern part), the presence of three ditches (repeating the plan of the settlement), and a high-rise observation deck with circular loopholes. In general, the period called the Kushan-Markhamat period was characterized by a developed fortification, when fortress walls with shooting galleries and rectangular towers were erected taking into account the power of battering machines (Sartepa, I-IV centuries AD). 
In general, it should be noted that the Markhamat period differs from the previous periods by the strengthening of the defense, which manifested itself not only by building additional walls (on Mingtepa, Arktepa), but also, by strengthening (bypass shooting galleries and towers) and improving the layout of the citadels (cruciform layout of the premises on Mingtepa), in which the towers were used as flank protection, and the gateway (on Arktepa, the so-called "fort" of a cruciform shape was attached to the southern flanking tower) [4, p. 132].

In the early medieval period, the fortress walls of many settlements lose their fortification value [9], repair and construction works were performed. There were no new fortification methods, the traditions of military architecture of the ancient period (up to the developed Middle Ages) were preserved, and the processes of powerful fortifications of the existing walls from the inside and outside were primarily due to political events (Akhsikent and Cuba). At that period, private fortification began to be actively developing, which could be observed in the example of castles and fortresses that played a dual role: "on the one hand, they were the residence of a feudal ruler, and on the other ... they protected the oasis from external invasions" [13, p. 96]. Such changes, observed throughout Central Asia, were caused by a change in social relations and the political structure of feudal castles. Due to the fact that they were supposed to be isolated (due to clashes between feudal lords), they were characterized by high stylobates (the height of the castle platform in Kalai-Bolo reached 8-9 m) and thick, wellfortified (sometimes not fortified) walls (the thickness of the castle walls in Zirtkepa reached $3.5 \mathrm{~m}$ ) with or without watchtowers.

Thus, already at the initial stage - in the Chust period, the military architecture was distinguished by its originality, largely due to the influence of nomadic traditions, and the traditions of erecting monolithic fortress walls were laid at that time. Although at that stage, the compliance with the so-called stable fortification canons (met in the southern regions of Central Asia) had not been observed yet, however, the main fortification elements in the form of a fortified citadel (in Chust and Dalverzin), powerful walls with shooting chambers and loopholes of various shapes (slit and arrow-shaped), ditches could be observed in Shurabashat period (in the example of the capital city Mingtepa).

Subsequently, in the Markhamat period, this type of architecture, depending on the level of development of the fortification itself, the function of the fortifications, and the relief of the area acquired the features of maturity and organization. During that period, along with rectangular towers (Mingtepa), rounded towers appeared (Arktepa, Araltepa, Gairattepa). The defense capacity of cities has also increased by the construction of additional walls, which gave the cities an impressive appearance. In the development of this architecture, one can observe the features of succession (continuation and transfer of the traditions of the Chust period into the Shurabashat period - an account for the relief features and the presence of a fill-in embankment lined with adobe bricks) and the evolutionary development: "the architecture of the Chust culture carriers has changed and lost elements of the architecture of nomadic relatives" [6, p. 61-68].

1. Abdulgazieva B. Eastern Fergana in antiquity and the early Middle Ages (settlement system, regionalization and typology) // Abstract of the thesis Cand. Hist. Sci. - Samarkand, 1988.

2. Abdulgazieva B. To the study of the structure of ancient cities of Fergana // IMKU. - Samarkand, 2004. - №34; Abdullaev B.M. To the study of defensive structures of the Fergana Valley of the antique period // IMKU. - Samarkand, 2004. - № 34.

3. Abdullaev B.M. To the study of defensive structures of the Fergana Valley of the antique period // IMKU. - Samarkand, 2004. - № 34.

4. Abdullaev B.M. On the history of ancient fortification of Fergana // IMKU. - Samarkand, 2006. №335.

5. Abdullaev B.M. The emergence and stages of development of the fortification of Fergana in antiquity and the Middle Ages (late II millennium BC - early II millennium AD) // Diss....Cand. Hist. Sci. Samarkand, 2007.

6. Abdullaev B.M. On the elements of nomadic culture in the fortifications of Fergana // Civilizations and cultures of Central Asia in unity and diversity // Materials of the International Conference. Samarkand, September 7-8, 2009 - Samarkand-Tashkent, 2010.

7. Abdullaev K. The most ancient states on the territory of Uzbekistan and their cultural links with ancient Eastern civilizations // Archeology of Uzbekistan. - Samarkand, 2011. - №1 (2).

8. Abdullaev B.M. The most ancient fortification of Fergana in the light of new research in Xinjiang (Late Bronze and Early Iron Age) // IMKU. - Samarkand, 2012. - № 37.

9. Anarbaev A. Akhsikent in antiquity and the Middle Ages (Results and prospects of research) // SA. M., 1988. - №1.

10. Anarbaev A.A. Once again about the localization of the capital cities of Fergana (Davan-Daiyuan) and some controversial issues related to them // Archeology of Uzbekistan. - Tashkent, 2010. - №1 (1).

11. Anarbaev A.A. Akhsikent is the capital of ancient Fergana. - Tashkent: Tafakkur, 2013.

12. Anarbaev A. Ancient Fergana and the Great Silk Road // J. Human capital. - M., 2019. - №2 (1220).

13. Brykina G.A., Gorbunova N.G. Fergana // Central Asia in the early Middle Ages. - M.: "Nauka", 1999. 
14. Zadneprovsky Yu.A. Chust culture in the Fergana Valley // Central Asia in the Age of Stone and Bronze. - M.-L.: "Nauka", 1966.

15. Zadneprovsky Yu.A. Fortifications of Chust settlements and their place in the history of the primitive fortification of Central Asia // KSIA. - M., 1976. - №. 147. - 5 p.

16. Zadneprovsky Yu.A. The main results of the study of the Chust village in Fergana (1952-1982) // IMKU. - Tashkent, 1984. - №19.

17. 14. Matbabaev B.Kh., Abdullaev B. Research on the western defensive wall of the settlement of Mingtepa // Archaeological research in Uzbekistan - 2001 - Tashkent, 2002.

18. Matbabaev B.Kh., Abdullaev B.M., Yuldashev B. Research of monuments of Fergana of the Late Bronze Age (Dalverzin, Ashkaltepa) // Archaeological research in Uzbekistan - 2004-2005. - Tashkent, 2006. Issue. 5.

19. Omuraliev D.D., Tentiev Zh.T., Tashkulov U.B. The architecture of ancient Kyrgyzstan. - Bishkek: ITC "TEKNIK", 2002.

20. Pugachenkova G.A. Ways of development of the architecture of Southern Turkmenistan during the time of slavery and feudalism. - M.: Publishing house of the Academy of Sciences of the USSR, 1958.

21. Rtveladze E.V. Fortifications on the northern borders of the Kushan state // Maskan. - Tashkent, 1992. № 5,6.

22. Rtveladze E.V. Kampyrtepa - its structure. Periodization // Materials of the Tokharistan expedition. Archaeological research in Kampyrtepa. - Tashkent, 2000. - Issue 1.

23. Rtveladze E.V. On the question of Petra; Ancient and medieval culture of Surkhandarya // Collection of articles dedicated to archaeological research in the Surkhandarya region of the Republic of Uzbekistan. - Tashkent, 2001.

24. Semenov G.L. Sogdian fortification of the 5th-8th centuries - St. Petersburg, 1996.

25. Turebekov M. Defensive structures of ancient settlements and cities of Sogd (VII-VI centuries BC - VII century AD). - Nukus: "Karakalpakstan", 1990. 